\title{
PKLR wt Allele
}

National Cancer Institute

\section{Source}

National Cancer Institute. PKLR wt Allele. NCI Thesaurus. Code C157137.

Human PKLR wild-type allele is located in the vicinity of $1 \mathrm{q} 22$ and is approximately $19 \mathrm{~kb}$ in length. This allele, which encodes pyruvate kinase PKLR protein, is involved in glycolysis. 